\title{
Detection of Toxoplasma gondii in aqueous humour by the polymerase chain reaction
}

\author{
F Aouizerate, J Cazenave, L Poirier, Ph Verin, A Cheyrou, J Begueret, F Lagoutte
}

\begin{abstract}
Ocular toxoplasmosis is the most frequent infectious cause of chorioretinal inflammation in immunocompetent patients. Nowadays, the biological diagnosis of ocular toxoplasmosis requires serological tests and anterior chamber puncture to detect the local production of specific antibodies. A new technique is described to detect Toxoplasma in aqueous humour by a polymerase chain reaction in which the target is a specific ribosomal DNA segment. Sixty eight patients (71 eyes) were included; $59(83 \%)$ eyes were suspected of having ocular toxoplasmosis. Of these 59 eyes, $15(25.4 \%)$ had characteristic fundus lesions with obvious intraocular inflammation signs and $44(75 \%)$ had retinal scar of ocular toxoplasmosis without clinically detectable inflammation. Twelve (17\%) eyes had uveitis of non-Toxoplasma origin and constituted the control group. The parasite was present in aqueous humour in $20(33.8 \%)$ cases. No false positives were detected. The sensitivity of the test is reduced by the low numbers of the sample. The combination of this technique with Witmer-Desmonts coefficient increases the probability of making a biological diagnosis of ocular toxoplasmosis. The physiopathological value of this technique is emphasised and the presence of tachyzoites in the anterior chamber is suggested. This should be a very promising technique for the diagnosis of ocular toxoplasmosis.

(BrF Ophthalmol 1993; 77: 107-109)
\end{abstract}

Ocular toxoplasmosis is the most common infectious cause of retinal inflammation of nonimmunocompromised patients. It accounts for $30-50 \%$ of all posterior uveitis.

The characteristic toxoplasmic lesion consists

Service d'Ophtalmologie, CHU Jean Abadie, 33077 Bordeaux Cedex, France F Aouizerate

L Poirier

$\mathrm{Ph}$ Verin

F Lagoutte

LABM, 30 allées de

Tourny, 33080 Bordeaux,

France

J Cazenave

A Cheyrou

CNRS (UA 542) et Université de Bordeaux

II, France

J Begueret

Correspondence to:

Dr F Aouizerate, Service

d'Ophtalmologie, Hôpital des d'Ophtalmologie, Hôpital des

Cedex, France

Accepted for publication 17 September 1992 of a massive coagulative necrosis of the retina with a granulomatous inflammation of the underlying choroid. ${ }^{12}$ Currently the diagnosis of ocular toxoplasmosis is made by observing the characteristic fundus lesion; by detecting the presence of anti-Toxoplasma antibodies in the patient's serum, and by excluding of other infectious diseases that might cause necrotising lesions of the fundus (principally syphilis, cytomegalovirus, and tuberculosis). ${ }^{34}$

In humans the incidence of antibodies to Toxoplasma increases with age. In Europe, particularly in France, the prevalence of antiToxoplasma antibodies is more than $90 \%$ by the fourth decade. In the United States it is estimated that $20-70 \%$ of adults have been infected with toxoplasmosis. ${ }^{5}$ Anterior chamber puncture (ACP) must therefore be performed especially in doubtful cases. ${ }^{4-9}$ The principle of this test on aqueous humour consists of determining the titre of anti-Toxoplasma antibodies in the aqueous humour, which is then compared with that in serum by the Witmer-Desmonts coefficient. These tests are significant when the antibody titre is higher in the aqueous humour. A new diagnostic method based on molecular biology ${ }^{10}$ is proposed here, by using a polymerase chain reaction (PCR)," to detect Toxoplasma in aqueous humour. This has been used successfully for tracing Toxoplasma in the amniotic fluid. ${ }^{12}$

Subjects and methods

This study was approved by the ethical committee of Bordeaux II University.

\section{SUBJECTS}

Sixty eight patients (71 eyes) were selected, 32 (47\%) men and $36(53 \%)$ women. The mean age was 23-18 (range 3-69).

Patients were divided into three groups:

Group I. Forty four (62\%) patients with retinal scar and who had an ACP in the past with a Witmer-Desmonts coefficient $\geq 4$.

Group II. Fifteen $(21 \cdot 1 \%)$ patients with characteristic fundus lesions and intraocular inflammation signs indicating ocular toxoplasmosis in acute phase.

Group III. Twelve (16.9\%) patients with posterior and/or anterior uveitis without clinical signs of a toxoplasmic origin, constituting the control group.

After a local anaesthetic or general anaesthesia with fluothane for young children, an ACP was performed by taking $0.2 \mathrm{ml}$ of aqueous humour after a limbic paracentesis with a microflex infusion gauge 27 needle. At the same time, a serological test determined the WitmerDesmonts coefficient.

The quantity of Toxoplasma antibodies in the serum and aqueous humour was evaluated by using the indirect fluorescent antibody test. Immunological load was the ratio between the anti-Toxoplasma antibody titre (IU) and the IgG concentration $(\mathrm{g} / \mathrm{l})$. The Witmer-Desmonts coefficient was calculated by comparing the concentration of anti-Toxoplasma antibodies divided by the concentration of $\gamma$ globulins in the aqueous humour to that in the serum. The coefficient was considered as positive when $\geq 4$.

Toxoplasma DNA in aqueous humour was detected by a PCR assay, in which the target was part of a ribosomal DNA (rDNA) repetitive gene, as described." An 88 base pair segment was amplified with the synthetic oligonucleotide 
Figure 1 Direct detection of Toxoplasma gondii DNA after ethidium bromide staining. Lanes 1-7, MW marker; lanes 2-3, negative specimens, lane 4, positive aqueous humour specimen; lane 5 , negative control; lane 6 , $\mathrm{T}$ gondii $D N A$ positive control.

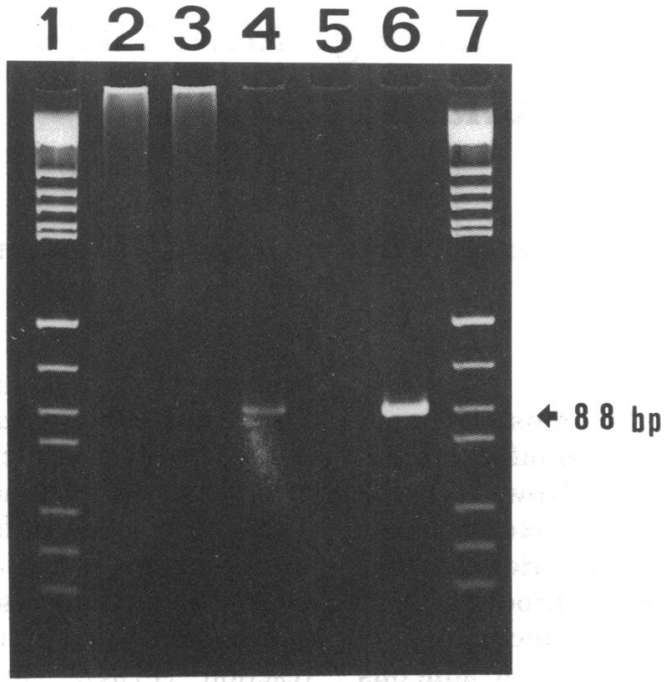

primers 5' CCTTGGCCGATAGGTCTAGG and 5' GGCATTCCTCGTTGAAGATT. DNA from aqueous humour was obtained, after centrifugation, by a proteinase $\mathrm{K}$-sodium dodecyl sulphate soft procedure according to Jeffreys $e t$ $a l .{ }^{13}$ Briefly, the pellets were digested for 1 hour at $37^{\circ} \mathrm{C}$ in $1.5 \mu \mathrm{l}$ of a buffer containing $5 \mathrm{mM}$ TRIS- $\mathrm{HCl}$ (pH 7.5), 3.4 mM sodium dodecyl sulphate $(0.01 \%), 40 \mathrm{mM}$ dithiothreitol, $50 \mu \mathrm{g} /$ $\mathrm{ml}$ proteinase $\mathrm{K}$, and $0 \cdot 1 \mu \mathrm{M}$ of each primer, followed by a heating step of 10 minutes at $95^{\circ} \mathrm{C}$.

After exposure to $95^{\circ} \mathrm{C}$ temperature for 10 minutes, DNA was amplified in a $50 \mu$ reaction mixture containing $10 \mathrm{mM}$ TRIS- $\mathrm{HCl}(\mathrm{pH} \mathrm{8.3)}$, $16 \mathrm{mM}\left(\mathrm{NH}_{4}\right)_{2} \mathrm{SO}_{4}, 2.5 \mathrm{mM}$ TRIS- $\mathrm{MgCl}_{2}$, $10 \mathrm{mM} 2$-mercaptoethanol, $1 \mathrm{mg} / \mathrm{ml}$ bovine serum albumin, $200 \mu \mathrm{l}$ of each of all four deoxyribonucleoside triphosphates, $1 \mu \mathrm{M}$ each of the two oligonueclotide primers and 1 unit of Taq polymerase (Cetus). Amplification in an automated DNA thermal cycler (Perkin Elmer Cetus) consisted of 35 cycles (denaturation step $95^{\circ} \mathrm{C}$ for 10 seconds, annealing step $64^{\circ} \mathrm{C}$ for 30 seconds and synthesis step $70^{\circ} \mathrm{C}$ for 1 minute), 10 $\mu \mathrm{l}$ of each amplification reaction was analysed on $10 \%$ polyacrylamide gel and the DNA fragments were visualised by staining with ethidium bromide (Fig 1).

\section{Results (Table 1)}

\section{CONTROLS}

After dilution of tachyzoites in human blood we observed that fewer than five cells could be efficiently and reproducibly detected, the detection of a single organism being possible in optimal conditions. When amplification was

Table 1 Biological results

\begin{tabular}{lcrc}
\hline & \multicolumn{2}{l}{ Groups } & \\
\cline { 2 - 4 } Biological tests & \multicolumn{1}{l}{$I$} & $I I$ & $I I I$ \\
\hline WDCandPCR+ & 5 & 1 & \\
WDCandPCR- & 12 & 6 & 12 \\
WDC+andPCR- & 17 & 4 & \\
WDC-andPCR+ & 10 & 4 & \\
Total & 44 & 15 & 12
\end{tabular}

WDC $=$ Witmer-Desmonts coefficient .

$\mathrm{PCR}=$ polymer chain reaction performed on purified Toxoplasma gondii DNA, less than 50 fg could be detected directly, which corresponds to the quantity of DNA in one parasite. Using hybridisation with an internal labelled probe after Southern blot analysis, it was possible to detect DNA corresponding to a single copy gene ( $1 \mathrm{fg})$.

\section{CLINICAL SPECIMENS}

\section{Group I}

The Witmer-Desmonts coefficient was $\geq 4$ in 22 $(50 \%)$ of cases. Toxoplasma DNA was detected in 15 (34\%) cases; of these 15 cases, the WitmerDesmonts coefficient was $>4$ in five $(11.3 \%)$ and $<4$ in $10(22 \cdot 7 \%)$ respectively. Of the $12(27 \cdot 2 \%)$ remaining patients, the Witmer-Desmonts coefficients were $<4$ and no Toxoplasma DNA was detected.

\section{Group II}

The Witmer-Desmonts coefficient was $\geq 4$ in five $(33 \cdot 3 \%)$ cases. Toxoplasma DNA was detected in five $(33.3 \%)$ cases, the WitmerDesmonts coefficient was $>4$ in one $(6 \cdot 6 \%)$ and $<4$ in four $(26.6 \%)$ respectively. Of the six $(40 \%)$ remaining patients, the Witmer-Desmonts coefficient was $<4$ and no Toxoplasma DNA was detected.

\section{Group III}

In all cases, the Witmer-Desmonts coefficient was $<4$ and the detection for Toxoplasma DNA was negative.

\section{Discussion}

There are several serological tests that demonstrate the presence of antibodies to Toxoplasma. However, because the prevalence of antibodies to Toxoplasma is high in certain communities, and since high titre antibodies may persist for years in otherwise healthy individuals, interpretation of these tests is often difficult. In countries such as France, $90 \%$ of adults have been infected with toxoplasmosis by the fourth decade. ${ }^{5}$ If the retinal lesion is atypical and the serological test is positive, diagnosis of Toxoplasma chorioretinitis is only presumptive because of the prevalence of antibodies in the population. In 1966 Desmonts described a method for comparing the ratio of anti-Toxoplasma antibodies in aqueous humour with those in serum. A coefficient of 4 or above is consistent with the intraocular production of specific anti-Toxoplasma antibodies, and suggests active ocular toxoplasmosis. ${ }^{5}$

We believe that the detection of Toxoplasma with PCR presents two main advantages: diagnostic and physiopathological.

In our series no false positive was noted (which confirms a high specificity), and with this technique, only one fragment of Toxoplasma DNA needed to be amplified for detection. The sensitivity of the test is, however, reduced by the low volume of the sample $(0.2 \mathrm{ml})$ which may mean that a tachyzoite goes undetected while being present in the anterior chamber. When the 
detection of Toxoplasma DNA is positive and the Witmer-Desmonts coefficient negative, this could indicate that:

(1) the activity of the ocular toxoplasmosis has been blocked by the local immunological response during the months before the $\mathrm{ACP}$;

(2) some free organisms (tachyzoites) could be present in the anterior chamber without a significantly clinical inflammatory response;

(3) the ACP is performed too early, before the Witmer-Desmonts coefficient becomes positive.

The detection of Toxoplasma DNA combined with the determination of the Witmer-Desmonts coefficient improves the probability of diagnosing ocular toxoplasmosis with biological tests. Indeed, if one compares the cases where the Witmer-Desmonts coefficient is $>4$ with those where the detection of Toxoplasma is positive, the biological diagnosis was made respectively in $50 \%$ and $34 \%$ of cases for group I, in $33.3 \%$ of cases for group II, and in $47 \cdot 7 \%$ and $34 \%$ of cases for both groups. If the cases are added where the Witmer-Desmonts coefficient was positive and those where Toxoplasma DNA detection was also positive, the biological diagnosis was made in $72.7 \%$ of cases for group I, in $60 \%$ of cases for group II, and in $69 \cdot 5 \%$ of cases for both groups.

Brezin $e t a l^{14}$ analysed samples of aqueous humour obtained from 17 patients with clinical symptoms consistent with ocular toxoplasmosis. Using PCR they detected Toxoplasma gondii DNA in the aqueous humour of three patients during two independent amplifications of the B1 gene fragment.

The various reports on the ultrastructural aspects of experimental ocular toxoplasmosis show the following: $:^{15} 16$

(1) intracellular cysts are localised in the inner retina and particularly in the ganglion cell layer;

(2) organisms remain free in the intercellular medium for relatively short periods;

(3) the inflammatory response concerns the choroid, the retina, and the vitreous;

(4) in immunocompromised hosts, Toxoplasma gondii may infect the iris, the choroid, and the vitreous, ${ }^{17}$ tissues that are not usually infected in the immunocompetent host. Using the highly sensitivite PCR, the presence of Toxoplasma gondii in the aqueous humour may be suggested.

\section{Conclusion}

Direct detection of Toxoplasma in aqueous humour can be a decisive complement to the diagnosis of ocular toxoplasmosis in certain atypical or clinically unclear cases. We report a PCR in which the target is a rDNA fragment.
In this work, we show the following:

(1) The high specificity of this technique (no false positive)

(2) The limited sensitivity of this test; this is because of the low volume of the sample which may preclude detection of Toxoplasma.

(3) An increased probability of making a biological diagnosis by means of the combination of this technique and the Witmer-Desmonts coefficient.

(4) The possible or probable presence of free parasites (tachyzoites) in the anterior chamber.

This technique promises to be effective for the diagnosis of ocular toxoplasmosis especially when combined with the Witmer-Desmonts coefficient.

1 Dutton GN. The causes of tissue damage in toxoplasmic retinochoroiditis. Trans Ophthalmol Soc UK 1986; 4: 404-12.

2 Dutton GN, McMenamin PG, Hay J, Cameron S. The ultrastructural pathology of congenital murine toxoplasmic ultrastructural pathology of congenital murine toxoplasmic matory changes. Exp Eye Res 1986; 4: 545-60.

3 Brezin AP, Eqwuagu CE, Burnier M, Silveira C, Mahdi RM, Gazzinelli RT, et al. Identification of Toxoplasma gondii in paraffin-embedded sections by the polymerase chain reaction. Am F Ophthalmol 1990; 6: 599-604.

4 Weinberg RS, Culbertson WW, Fischer DW, Rao NA, Schachat AP, Young SE. Intraocular inflammation, uveitis and ecular tumors. In: Richard JM, ed. Pediatric ophthalmology and strabismus. Basic and clinical science course: San Francisco: American Academy of Ophthalmology, 1989: $120-3$

5 Quilan P, Jabs DA. Ocular toxoplasmosis. In: Ryan SJ, ed. Retina. vol II. St Louis: Mosby, 1989: 563-74.

6 Kijlstra A, Luyendijk L, Baarsma GS, Rothova A, Schweitzer CMC, Timmerman Z, et al. Aqueous humor analysis as a diagnostic tool in toxoplasma uveitis. Int Ophthalmol 1989; 6: $383-6$.

7 Malecaze F, Bessieres MH, Mathis A, De Chasteigner V, Seguela JP. Diagnostic de la toxoplasmose oculaire au moyen de la methode immuno-enzymatique ELISA. Ophtalmologie 1987; 2: 285-7.

8 Payeur G, Bijon JC, Pagano N, Kien T, Candolfi E, Penner MF. Diagnosis of ocular toxoplasmosis by the ELISA method. F Fr Ophtalmol 1988; 1: 75-9.

9 Verin P, Comte P, Capsec F, Harroche S. La toxoplasmose oculaire recidivante doit être traitée. Bull Soc Fr Ophtalmol 1986; 12: 1563-8.

10 Saiki RK, Gelfand DH, Stoffel S, Scharf SJ, Higuchi R, Horn GT, et al. Primer directed enzymatic amplification of DNA with a thermostable DNA polymerase. Science 1988; 239: with a ther

11 Cazenave J, Bessieres MH, Sourrue D, Cheyrou A, Begueret J. Detection de toxoplasmes par amplification d'ADN. Rev Fr Lab 1990; 209: 118-26.

12 Cazenave J, Forestier F, Bessieres MH, Broussin B, Begueret J. Contribution of a new PCR assay to the prenatal diagnosis of congenital toxoplasmosis. Prenat Diagn 1992; 12: 119-27.

13 Jeffreys AJ, Wilson V, Neumann R, Keyte J. Amplification of human minisatellites by the PCR: towards DNA fingerprinting of simple cells. Nucl Acids Res 1988; 16: 10953-71.

14 Brezin AP, Eqwuagu CE, Silveira C, Thulliez Ph, Martins MC, Mahdi RM, et al. Analysis of aqueous humor in ocular toxoplasmosis. N Engl f Med 1991; 10: 699 .

15 Lai S, Terragnac FM, Berttagno R, Ceppa P, Canessa A, Vitrone P. Aspects ultrastructuraux de la toxoplasmose oculaire expérimentale. Bull Soc Fr Ophtalmol 1986; 97: oculaire

16 McMenamin PG, Dutton GN, Hay J, Cameron S. The ultrastructural pathology of congenital murine toxoplasmic retinochoroiditis. Part I: the localisation and morphology of toxoplasma cysts in the retina. Exp Eye Res 1986; 4: 529-43.

17 Holland GN. Ocular toxoplasmosis in the immunocompromised host. Int Ophthalmol 1989; 6: 399-402. 